\title{
STUDI AGIHAN SALINITAS AIRTANAH DANGKAL DI KECAMATAN PURING KABUPATEN KEBUMEN TAHUN 2016
}

\author{
Muhamad Fatoni ${ }^{* 1}$, Chatarina Muryani*2 ${ }^{2}$, Setya Nugraha ${ }^{* 3}$ \\ ${ }^{1,2,3}$ Program Studi Pendidikan Geografi, FKIP, UNS Surakarta \\ Email: muhamadfatoni911@gmail.com
}

\begin{abstract}
The purpose of this study is (1) Determine the spatial distribution of shallow groundwater salinity in Subdistrict Puring, District Kebumen 2016, (2) Knowing the public perception of the groundwater condition in the District Puring 2016, and (3) know the implementation of research results for high school geography learning material grade X curriculum 2013

This study used a qualitative method with a spatial approach. The technique of taking research subjects in this study using Transect Line Plots. The technique of collecting data using interviews, observation and analysis of secondary data. Analysis of the data in this study using the analysis of matching, and scoring.

The results showed that: (1) Spatial Distribution shallow groundwater salinity in the Subdistrict Puring concentrated in the south or near the beach, it means getting closer to the sea, the higher salinity value. (2) The public perception of the condition of groundwater in the Subdistrict Puring, included in the medium classification, it's means that people have started to know if they are a potential area groundwater in their wells polluted and have a fairly high salinity values. (3) Implementation of the results of this study are presented in the form of learning modules Geography class X High School Curriculum 2013, which contains material on groundwater and salinity.
\end{abstract}

Keywords: salinity, public perception, groundwater

\section{PENDAHULUAN}

Airtanah adalah sejumlah air di bawah permukaan bumi yang dapat dikumpulkan dengan sumur-sumur, terowongan atau sistem drainase atau dengan pemompaan. Dapat juga disebut air yang terdapat dalam lapisan tanah atau batuan di bawah permukaan tanah (Kodoatie 2012: 39 - 43). Sedangkan airtanah dangkal adalah air yang berada di bawah permukaan tanah hingga kedalaman $90 \mathrm{~m}$ dari permukaan tanah, mengisi pori-pori tanah di atas lapisan batuan kedap air dalam tanah. Airtanah ini membentuk permukaan air sebagaimana permukaan air pada sumur-sumur penduduk (PP No. 42 tahun 2008 tentang Pengelolaan Sumber Daya Air). Airtanah memiliki peranan penting dalam kehidupan manusia, salah satu peranan pentingnya adalah sebagai penyedia sumber air bersih untuk bahan baku air minum yang paling tinggi mutunya dibandingkan dengan sumber air lainnya. Hal 
ini karena airtanah berada di dalam tanah dan memiliki kualitas yang tinggi.

Airtanah ditemukan pada formasi geologi permeable (tembus air) yang dikenal sebagai akuifer (juga disebut reservoir airtanah, formasi pengikat air, dasar- dasar yang tembus air) yang merupakan formasi pengikat air yang memungkinkan jumlah air yang cukup besar untuk bergerak melaluinya pada kondisi lapangan yang biasa (Seyhan, 1990 dalam Indahwati 2012: 12). Pergerakan airtanah pada hakekatnya terdiri atas pergerakan horizontal airtanah; infiltrasi, sungai, danau, dan rawa ke lapisan akuifer; dan menghilangnya atau keluarnya airtanah melalui spring (sumur), pancaran airtanah (mata air), serta aliran airtanah memasuki sungai dan tempat-tempat lain yang merupakan tempat keluarnya airtanah (Hamzah, 2011 dalam Damayanti, 2015: 3).

Seiring dengan pertambahan jumlah penduduk yang selalu meningkat, kebutuhan airtanah pun juga selalu meningkat. Setiap hari manusia selalu membutuhkan air untuk memenuhi berbagai macam kebutuhan. Kebutuhan air bagi manusia yang paling utama diantaranya adalah untuk kebutuhan domestik sehari-hari seperti memasak, mandi dan mencuci. Kebutuhan air bagi manusia lainnya adalah untuk industri, irigasi pertanian, jasa dan penyediaan air perkotaan.
Peningkatan pemanfaatan air ini dapat dijumpai pada daerah-daerah yang padat penduduk, daerah permukiman baru dan daerah industri.

The groundwater salinity is an important groundwater quality indicator, which is controlled by the factors such as precipitation, evapotranspiration, mineralogy, type of aquifers, topography, and seawater intrusion (Shao-feng Yan, dkk 2014: 1).

Peningkatan pemanfaatan airtanah untuk mengairi area persewahan menjadi faktor utama penyebab tercemarnya airtanah di Kecamatan Puring. Pada musim kemarau petani di Kecamatan Puring banyak membutuhkan air, namun sistem drainase disana masih kurang baik. Maka masyarakat menggunakan cara lain untuk mengairi sawah dengan cara membuat sumur bor di area persawahan guna mencukupi kebutuhan air untuk mengairi tanaman mereka. Pengambilan air dengan pompa yang kemudian digunakan untuk mengairi area persawahan ini terus menerus dilakukan tanpa difikirkan dampaknya. Pemanfaatan airtanah yang berlebihan ini lah yang menjadi penyebab utama tercemarnya airtanah oleh tingginya nilai salinitas. 
Semakin meningkatnya penggunaan airtanah, maka perlu dilakukan wawancara kepada masyarakat di daerah penelitian berkaitan dengan persepsi masyarakat terhadap kondisi airtanah. Menurut Slameto (2010: 102) persepsi merupakan proses yang menyangkut masuknya pesan atau informasi kedalam otak manusia, melalui persepsi manusia terus menerus mengadakan hubungan dengan lingkungannya. Sedangkan yang dimaksud dengan masyarakat adalah sekelompok manusia yang hidup dalam satu kesatuan dalam tatanan sosial masyarakat.

Tujuan penelitian ini adalah sebagai berikut: (1) Untuk Mengetahui agihan spasial salinitas airtanah dangkal di Kecamatan Puring, Kabupaten Kebumen Tahun 2016. (2) Untuk Mengetahui persepsi masyarakat terhadap kondisi airtanah di Kecamatan Puring Tahun 2016. (3) Untuk mengetahui implementasi hasil penelitian untuk materi pembelajaran geografi SMA kelas X Kurikulum 2013.

\section{METODE PENELITIAN}

Penelitian ini dilakukan di kawasan pesisir Kecamatan Puring yang secara administrasi berada di Kabupaten Kebumen. Kawasan pesisir Kecamatan Puring dipilih karena letaknya yang dekat dengan laut dan terdapat permasalahan pemanfaatan airtanah yang berlebihan. Pembuatan sumur bor di sawah yang terus bertambah dan terusmenerus digunakan untuk mengairi tanaman sangat mempengaruhi kondisi airtanah dan menimbulkan potensi tercemarnya airtanah akibat dari intrusi air laut.

Penelitian ini menggunakan metode kualitataif dengan pendekatan spasial. Populasi dalam penelitian ini adalah 8 desa yang letaknya paling dekat dengan laut. Sampel dalam penelitian ini adalah sumur warga dengan ketentuan jarak dari masingmasing sumur adalah $500 \mathrm{~m}$. Sampel yang di ukur salinitasnya berjumlah 101 sampel. Teknik pengumpulan data menggunakan observasi, wawancara, dan dokumentasi. Teknik analisis data menggunakan metode matching atau pencocokan antara nilai salinitas masing-masing sumur warga dengan klasifikasi nilai salinitas. Terdapat empat klasifikasi nilai salinitas menurut Goetz (1986), dalam Ribut (2013: 9) akan disajikan pada tabel 1 berikut ini.

Tabel 3. Kriteria Penilaian Salinitas Air Sumur

\begin{tabular}{cll}
\hline No & Salinitas (\%) & Klasifikasi \\
\hline 1 & $<0,05$ & Air tawar \\
2 & $0,05-3,00$ & Air payau \\
3 & $3,00-5,00$ & Air asin \\
4 & $>5$ & Brine \\
\hline
\end{tabular}

Sumber: Goetz (1986), dalam Budiyono (2013: 9)

Analisis data hasil wawancara menggunakan metode skoring. Setelah 
analisis skoring selesai, maka selanjutnya akan dicocokan dengan klasifikasi tingkat persepsi masyarakat. Klasifikasi tingkat persepsi masyarakat terhadap kondisi airtanah menggunakan formula yang dikemukakan Dibyosaputro (1999) dalam Hermon (2012), yaitu:

Rumus klasifikasi :

$$
\begin{aligned}
& I=\frac{c-b}{k} \\
& I=\frac{24-8}{3} \\
& I=\frac{16}{3} \\
& I=5,33
\end{aligned}
$$

Keterangan :

$\mathrm{I}=$ besar jarak interval kelas

$\mathrm{c}=$ jumlah skor tertinggi

$\mathrm{b}=$ jumlah skor terendah

$\mathrm{k}=$ jumlah kelas yang di inginkan

Berdasarkan hasil perhitungan, klasifikasi persepsi masyarakat terhadap kondisi airtanah dapat disajikan pada

\begin{tabular}{|c|c|c|c|c|}
\hline Klasifikasi & Skor & $\begin{array}{l}\text { Tingkat } \\
\text { Persepsi }\end{array}$ & $\begin{array}{ll}\text { Keterangan } & \text { nilai satinitas } 2 \% \text {. Sampel } \\
& \text { solinitas } 0 \% \text { termasuk dalam }\end{array}$ & 1 dengan nil \\
\hline I & $>18,66$ & Tinggi & $\begin{array}{l}\text { Sudah paham dan ada } \\
\text { tindakan tawar, sedangkan sampel }\end{array}$ & dengan ni \\
\hline II & $13,33-18,66$ & Sedang & $\begin{array}{l}\text { Sudah paham tapi belum } \\
\text { ada tindakan }\end{array}$ & \\
\hline III & $8-13,33$ & Rendah & Belum paham & \\
\hline
\end{tabular}
tabel.

Tabel 4. Klasifikasi Tingkat Persepsi Masyarakat

\section{HASIL DAN PEMBAHASAN}

Penelitian ini menghasilkan informasi persebaran nilai salinitas airtanah dangkal di Kecamatan Puring bagian selatan. Berdasarkan informasi nilai salinitas selanjutnya akan dibuat peta persebaran salinitas airtanah dangkal di Kecamatan Puring bagian selatan. Hasil analisis wawancara menghasilkan informasi persepsi masyarakat mengenai kondisi airtanah dangkal di Kecamatan Puring.

Pengukuran sampel nilai salinitas airtanah dangkal menggunakan metode line plots transect, yaitu membuat garis menuju ke arah darat dengan memberi jarak 500 m untuk setiap sampel yang diukur. Dengan membuat grasi transek ini akan memudahkan dalam pengambilan sampel dan datanya akan lebih akurat. Sampel nilai salinitas airtanah dangkal diukur menggunakan alat refraktometer dengan satuan $\%$.

Hasil pengukuran nilai salinitas airtanah dangkal dari 101 sampel adalah 26 sampel dengan nilai salinitas 0\%, 37 sampel dengan nilai salinitas 1\%, 14 sampel dengan nilai salinitas $1,5 \%$, dan 24 sampel dengan 
salinitas $1 \%$ - $2 \%$ termasuk dalam klasifikasi air payau.

Titik sampel airtanah dangkal yang termasuk dalam klasifikasi payau dengan jarak terjauh terletak di Desa Kaleng dan Tukinggedong. Hasil perhitungan nilai salinitas ini merupakan temuan yang mengejutkan bagi peneliti, karena letaknya yang jauh dari laut kurang lebih 3-4 km. Terlebih lagi titik sampel yang berada di sebelah selatannya memiliki nilai salinitas 0 atau termasuk air tawar. Rata-rata airtanah dangkal yang nilai salinitasnya termasuk payau berada pada jarak kurang dari $1 \mathrm{~km}$, hanya sedikit saja yang lebih dari $1 \mathrm{~km}$.

Pada saat pengukuran sampel airtanah, didapatkan sebuah temuan lain di Desa Banjarejo yang memiliki nilai salinitas $2 \%$, ini merupakan nilai yang tinggi mengingat jaraknya sekitar $3-4 \mathrm{~km}$ dari laut. Berdasarkan informasi yang peneliti terima, ternyata daerah Kecamatan Puring bagian utara diduga terdapat conate water(jebakan air laut). Hal inilah yang menyebabkan air di daerah Kecamatan Puring bagian utara air sumurnya terasa payau dan berwarna keruh. Selain karena adanya conate water, payaunya air di beberapa bagian utara daerah penelitian juga disebabkan oleh sungai yang tercemar oleh pasang surut air laut. Selain itu ada kemungkinan disebabkan oleh adanya rawa belakang di daerah penelitian yang dapat dilihat dengan adanya air yang menggenang dalam waktu yang lama.

Pada saat pengukuran sampel, dilakukan plotting lokasi pengukuran sampel. Tujuannya adalah untuk membuat peta persebaran salinitas airtanah dangkal di Kecamatan Puring. Setiap lokasi pengukuran sampel di plotting dengan menggunakan GPS atau Global Positioning System. Langkah berikutnya adalah membuat peta persebaran salinitas airtanah dangkal.

Hasil analisis data pengukuran nilai salinitas airtanah dangkal menunjukkan jika semakin jauh jarak titik sampel airtanah dangkal, dalam hal ini adalah air sumur warga dengan laut maka nilai salinitasnya semakin kecil atau rendah. Semakin dekat jarak sampel nilai salinitas airtanah dangkal dengan laut, maka nilai salinitasnya semakin tinggi. Jadi tinggi atau rendah nilai salinitas dipengaruhi oleh jarak dari laut. Berikut informasi nilai salinitas airtanah dangkal di Kecamatan Puring yang disajikan pada Gambar 1. 


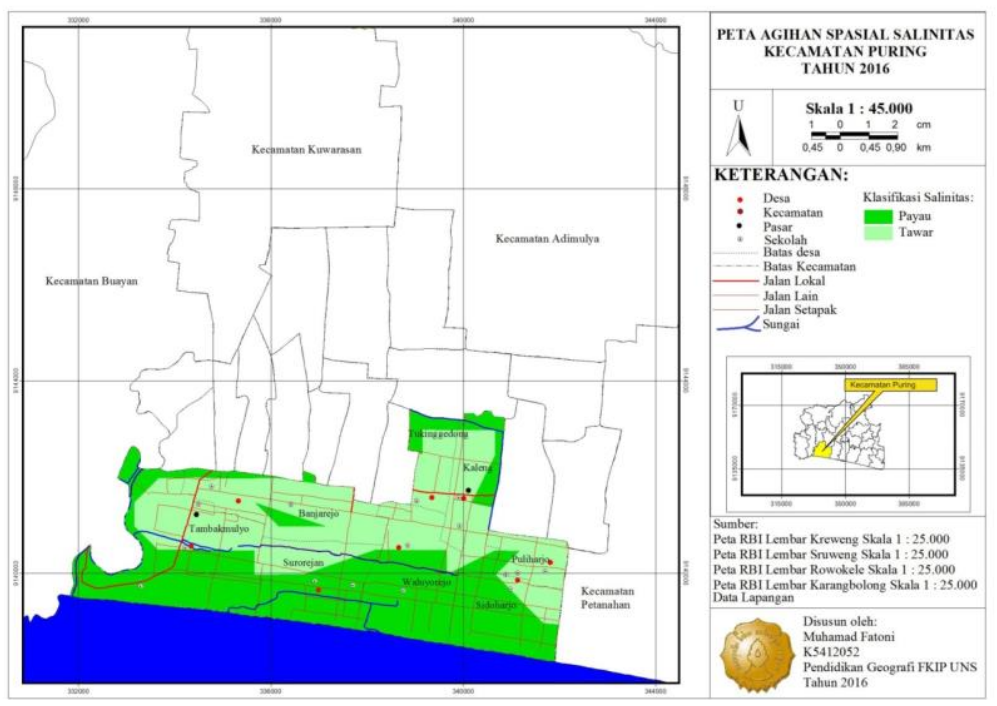

Gambar 1. Peta Agihan Spasial Salinitas Airtanah Dangkal di Kecamatan Puring

Peta Agihan Spasial Salinitas Airtanah Dangkal dan hasil plotting titik sampel kemudian akan digunakan sebagai dasar dalam pembuatan Peta Kontur Salinitas Airtanah Dangkal. Dari data plotting akan diolah menggunakan metode Three Point Problem. Pertama adalah menghubungkan tiga titik plotting sampel, kemudian akan dibuat interval kontur salinitas. Peneliti menentukan interval yang digunakan adalah 0,25 . Berikutnya adalah interpolasi, yaitu menghubungkan nilai-nilai yang sama untuk kemudian menjadi Peta Kontur Salinitas. Berikut informasi mengenai kontur salinitas airtanah dangkal akan disajikan pada Gambar 2.

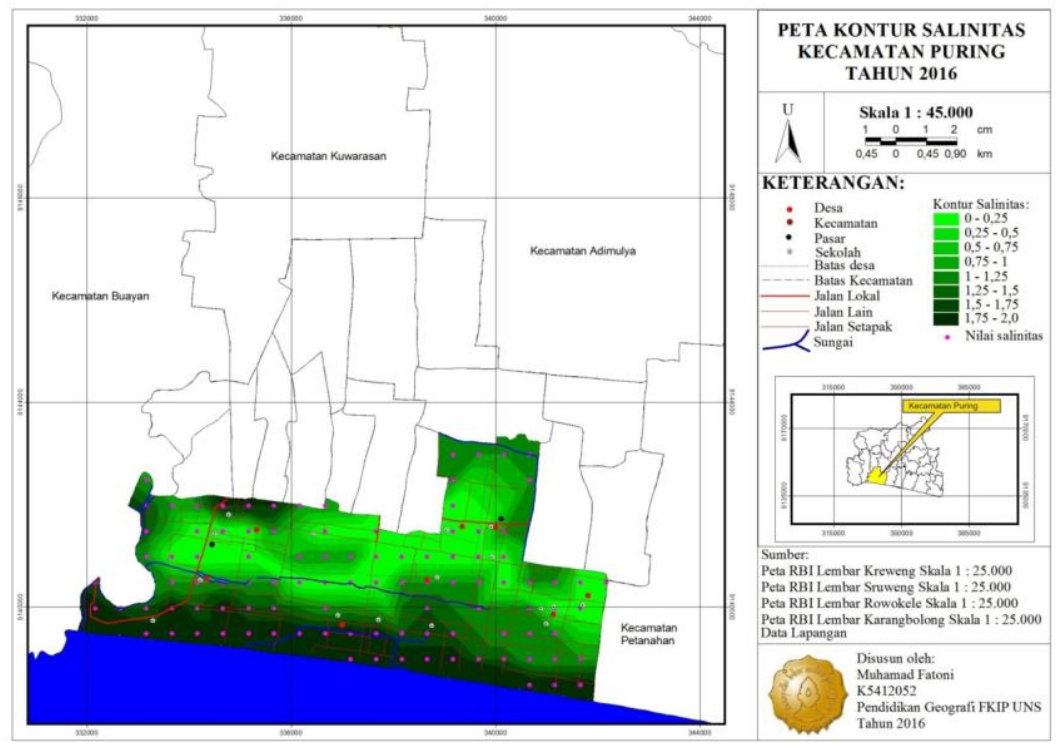

Gambar 2. Peta Kontur Salinitas Airtanah Dangkal di Kecamatan Puring 
Berdasarkan Peta Kontur Salinitas Airtanah Dangkal, terdapat 3 pola kontur salinitas pada daerah penelitian, sebagai berikut:

a) Pola kontur 1, terletak di bagian timur daerah penelitian, dengan ciri-ciri menjorok ke utara membentuk lancip. Airtanah tanah yang tercemar air laut sudah mencapai $2 \mathrm{~km}$, sehingga airtanahnya terasa payau. Diduga penyebabnya adalah adanya jebakan air laut (conate water) hingga membuat air yang berada di daerah ini rasanya payau. Berikut ini grafik pola kontur 1 akan disajikan pada Gambar 3. Pola Kontur Salinitas 1.

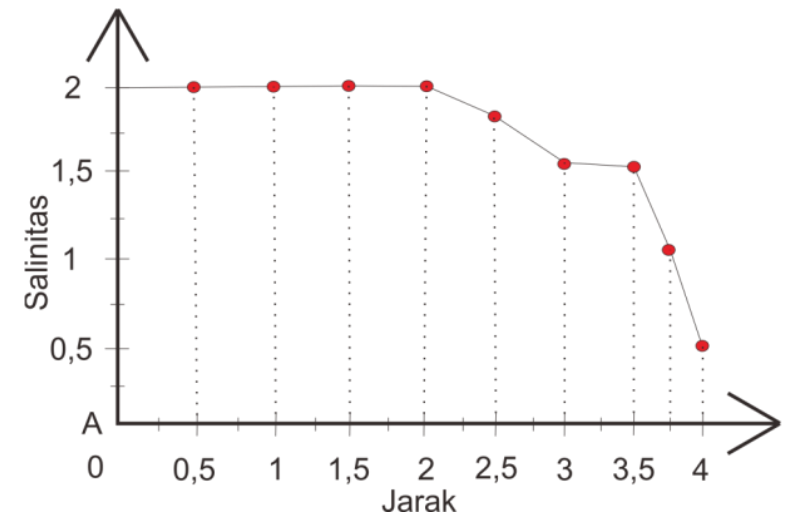

Gambar 3. Pola Kontur Salinitas 1

b) Pola kontur 2, terletak di bagian tengah daerah penelitian, dengan ciri-ciri berbentuk datar, pola konturnya rata. Airtanah yang sudah terasa payau baru sejauh sekitar $1 \mathrm{~km}$. Jadi semakin jauh jarak sumur dengan laut maka nilai salinitasnya semakin rendah. Berikut ini grafik pola kontur 1 akan disajikan pada Gambar 4. Pola Kontur Salinitas 2

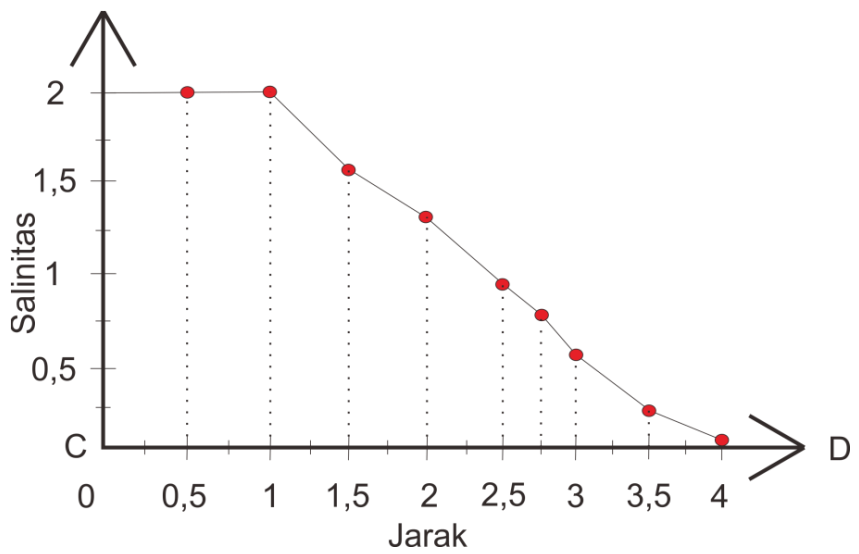

Gambar 4. Pola Kontur Salinitas 2

c) Pola kontur 3, terletak di bagian barat daerah penelitian, dengan ciri-ciri berbentuk seperti bukit, namun terdapat daerah yang airtanahnya terasa payau berada jauh dari laut serta dipisahkan oleh airtanah yang tawar. Hal ini bisa terjadi karena pada daerah ini terletak pada daerah jebakan air laut (conate water). Berikut ini grafik pola kontur 3 akan disajikan pada Gambar 5. Pola Kontur Salinitas 3.

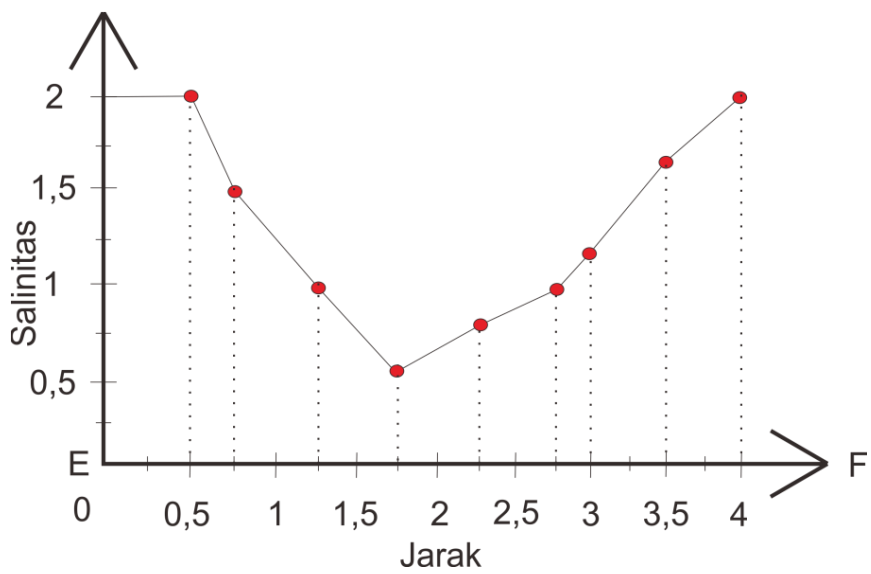

Gambar 5. Pola Kontur Salinitas 3

Penelitian ini juga menggunakan wawancara untuk mengetahui persepsi masyarakat terhadap kondisi airtanah dangkal di Kecamatan Puring. Wawancara dilakukan 
dengan cara membagi wilayah wawancara menjadi tiga wilayah, yaitu wilayah satu desa dengan jarak <300 m dari pantai. Wilayah dua desa dengn jarak $300-600$ m dari pantai. Wilayah tiga desa dengan jarak $>600 \mathrm{~m}$ dari pantai. Jumlah responden yang di wawancarai sebanyak 60 responden dengan pembagian masing-masing wilayah 20 responden.

Berdasarkan wawancara yang telah dilakukan oleh peneliti menunjukkan bahwa hampir seluruh responden menyatakan bahwa airtanah dalam sumur rasanya tawar dan sama sekali tidak asin. Baik airtanah yang terletak dekat dengan pantai atau yang jauh dari pantai. Hanya saja beberapa warga yang rumahnya dekat dengan pantai mengatakan bahwa sudah ada perubahan rasa agak payau. Tinggi muka air sumur terjadi perubahan yang bervariasi ketika musim penghujan dan kemarau. Rata-rata perubahan tinggi muka air sumur antara 2-3 m ketika musim kemarau.

Analisis data wawancara diolah menggunakan metode skoring. Skor terendah dari hasil wawancara terhadap responden mengenai kondisi airtanah dangkal adalah dengan skor 15. Skor tertinggi dari hasil

wawancara yang dilakukan oleh peneliti adalah dengan skor 21. Sedangkan skor yang paling banyak di dapatkan dalam wawancara terhadap masyarakat adalah dengan skor 18 . Skor total hasil wawancara terhadap 60 responden yaitu 1098. . Dari total skor 60 responden akan di hitung rata-rata skornya dengan cara total skor 60 responden dibagi jumlah responden yaitu 60. Maka total skor 1098 dibagi 60 responden, hasilnya adalah 18,3. Jadi skor rata-rata dari hasil wawancara peneliti terhadap 60 responden mengenai kondisi airtanah dangkal di dalam sumur warga adalah 18,3.

Hasil plotting titik wawancara dan analisis data skoring hasil wawancara terhadap masyarakat di Kecamatan Puring dapat digunakan untuk membuat peta kontur persepsi masyarakat. Pembuatan peta kontur persepsi menggunakan metode three point problem, dengan kontur interval 1. Berikut disajikan Peta Kontur Persepsi Masyarakat terhadap kondisi airtanah dangkal di Kecamatan Puring Tahun 2016 pada Gambar 6. 

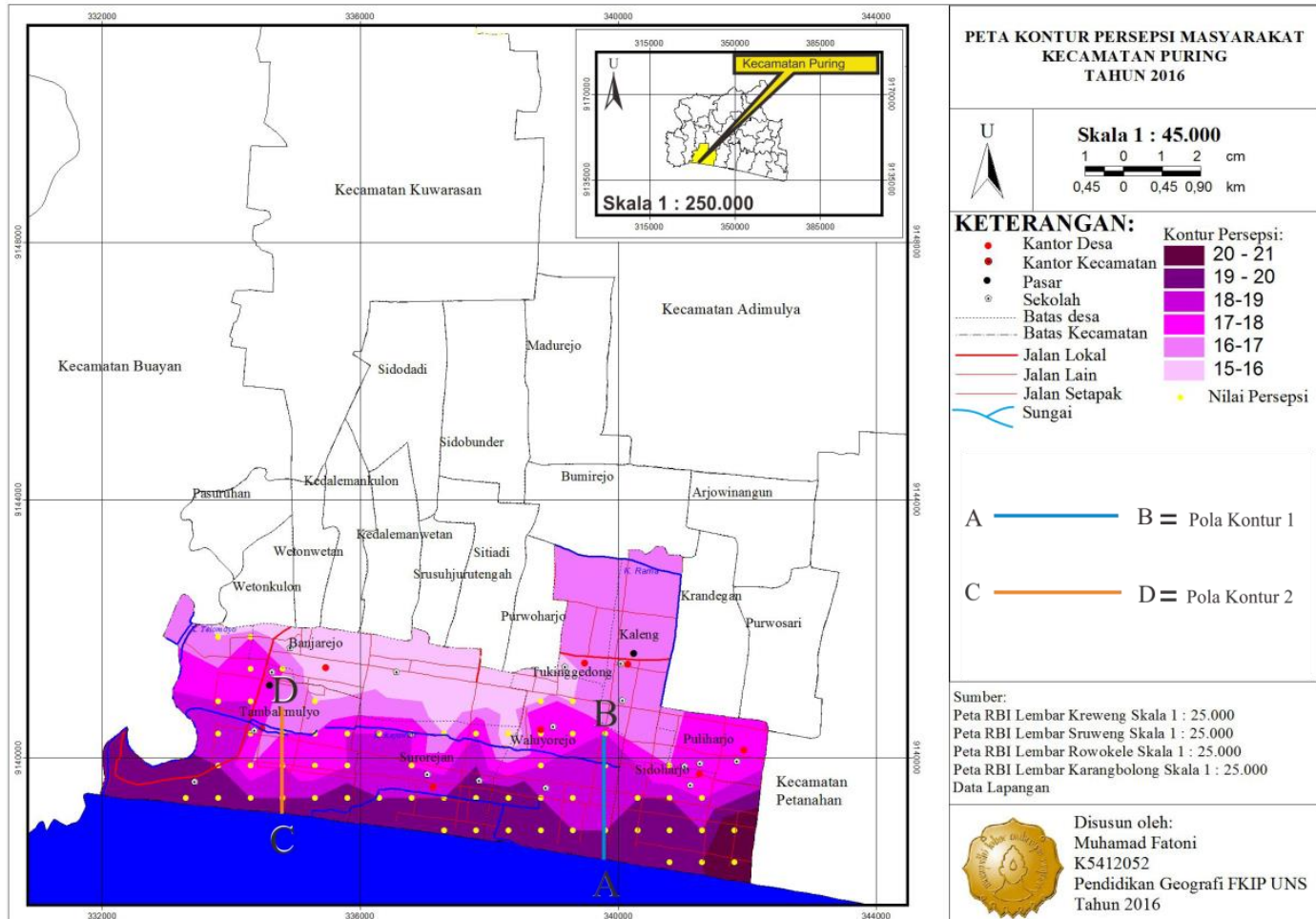

Gambar 6. Peta Kontur Persepsi Masyarakat Kecamatan Puring

Berdasarkan Peta 6 Peta Kontur

Persepsi Masyarakat, terdapat dua pola kontur persepsi. Pola pertama terletak di bagian timur daerah penelitian, dimana pola satu menunjukkan jika ternyata jarak tidak mempengaruhi persepsi masyarakat terhadap kondisi airtanah dangkal. Karena pada pola pertama, jarak laut dengan rumah responden mencapai 2,5 km, akan tetapi persepsinya tinggi. Hal ini di akibatkan oleh faktor pendidikan, dimana pada pola pertama ini responden yang ditemui memiliki jenjang pendidikan yang tinggi sehingga mempengaruhi persepsi. Berikut ini disajikan grafik pola kontur 1 pada Gambar 7. Pola Kontur Persepsi 2.

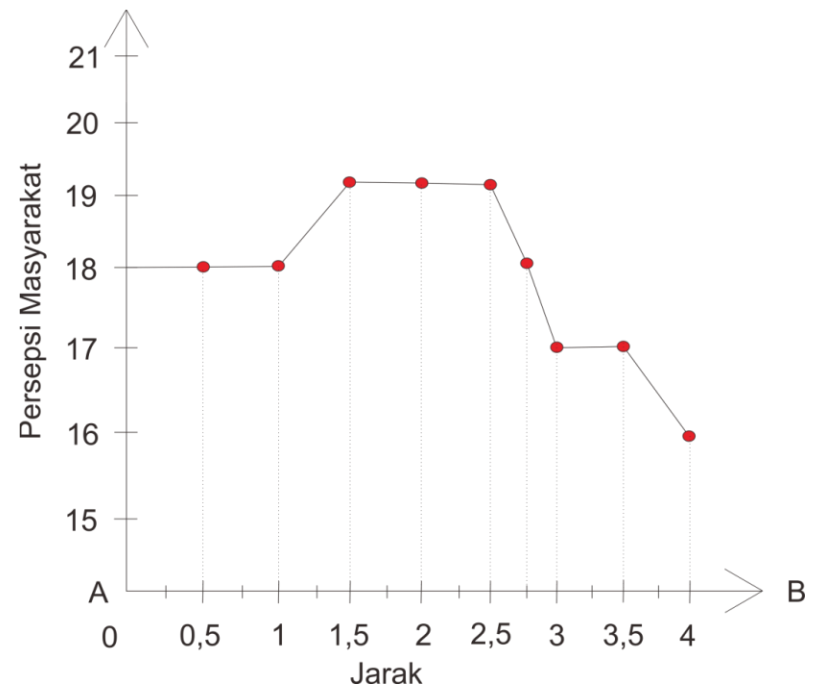

Gambar 7. Pola Kontur Persepsi 1

Pola kedua terletak di bagian barat daerah penelitian, dimana pola dua menunjukkan jika semakin jauh jarak responden yang diwawancarai, maka persepsi masyarakat terhadap kondisi airtanah semakin 
rendah. Berikut ini grafik pola kontur persepsi 1 akan disajikan pada Gambar 8. Pola Kontur Persepsi 1.

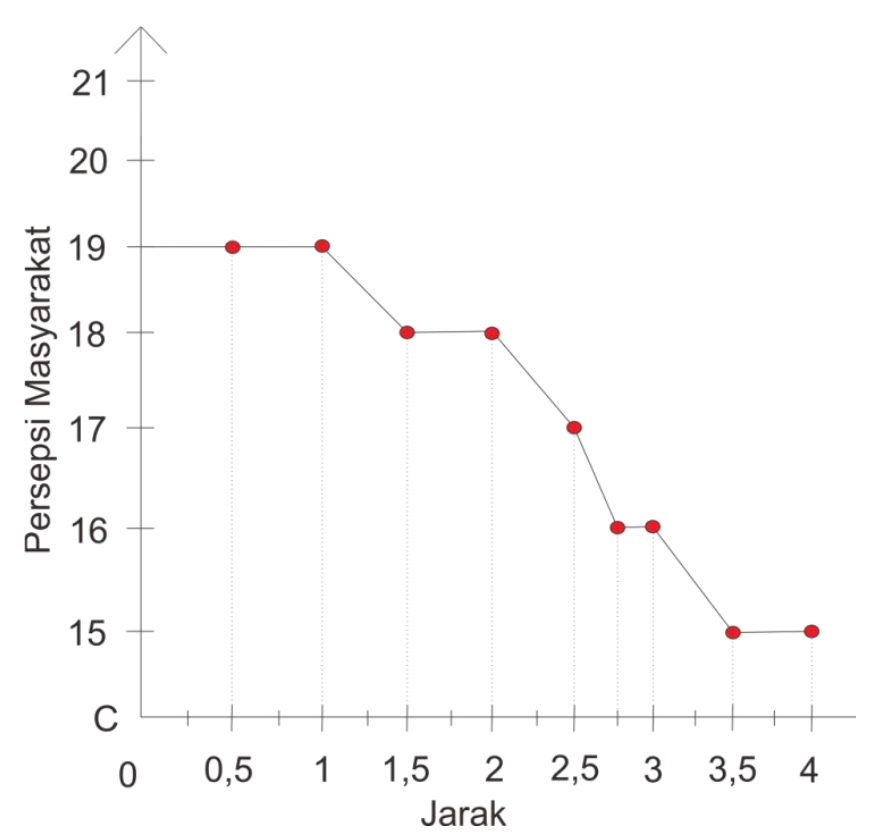

Gambar 8. Pola Kontur Persepsi 2

Langkah berikutnya adalah membuat klasifikasi Persepsi Masyarakat Terhadap Kondisi Airtanah di Kecamatan Puring. Terdapat 3 klasifikasi persepsi masyarakat terhadap kondisi airtanah dangkal, yaitu tinggi dengan skor $>18,66$, sedang dengan skor 13,33 - 18,66, dan rendah dengan skor 8 - 13,33. Berdasarkan nilai rata-rata hasil skoring wawancara terhadap 60 responden yaitu dengan skor 18,3. Maka dapat di simpulkan bahwa persepsi masyarakat terhadap kondisi airtanah dangkal di Kecamatan Puring tahun 2016 termasuk dalam klasifikasi sedang. Artinya masyarakat sudah mulai mengetahui jika wilayah mereka terdapat potensi terjadinya intrusi air laut yang menyebabkan airtanah di sumur mereka tercemar dan memiliki nilai salinitas yang cukup tinggi. Dengan hasil ini, masyarakat harus lebih bijaksana dan arif dalam memanfaatkan airtanah. Dengan begitu tidak akan ada pemanfaatan airtanah yang berlebihan dan mengurangi resiko terjadinya intrusi air laut.

\section{SIMPULAN}

Berdasarkan hasil penelitian dan pembahasan, maka dapat ditarik kesimpulan sebagai berikut.

1. Agihan spasial salinitas airtanah dangkal di Kecamatan Puring terbagi menjadi dua wilayah, yakni wilayah airtanah tawar dengan nilai salinitas $0 \%$ yang meliputi bagian tengah sampai utara daerah penelitian. Wilayah airtanah payau dengan nilai salinitas $1-2 \%$ yang menempati bagian tengah sampai selatan daerah penelitian. Semakin dekat dengan laut maka salinitasnya semakin tinggi, sebaliknya semakin jauh dari laut maka nilai salinitasnya semakin rendah.

2. Persepsi masyarakat terhadap kondisi airtanah dangkal di Kecamatan Puring termasuk dalam klasifikasi sedang, artinya masyarakat sudah mulai mengetahui jika wilayah mereka terdapat potensi airtanah di sumur mereka tercemar dan memiliki nilai salinitas yang cukup tinggi. 
3. Implementasi hasil penelitian ini disajikan dalam bentuk modul pembelajaran Geografi SMA kelas X Kurikulum 2013 yang memuat materi tentang airtanah dan salinitas.

\section{DAFTAR PUSTAKA}

Budiyono, Ribut. 2013. Pengaruh Salinitas Terhadap Pertumbuhan Ikan Sidat Fase Glass Eel Sebagai Alternatif Teknologi Budidaya Ikan Sidat (Anguilla bicolor bicolor). Skripsi FMIPA UNS.

Damayanti, Annisa Dwi. 2015. Studi Salinitas Air Tanah Dangkal di Daerah Pesisir Bagian Utara Kota Makassar. Skripsi FT UNHAS.

Hermon, dedi. 2015. Geografi Bencana Alam. PT Rajagrafindo Persada: Jakarta.

Indahwati, N. 2012. Studi Salinitas Air Tanah Dangkal di Kecamatan Ulujami Kabupaten Pemalang Tahun 2012. Skripsi FKIP UNS.

Kodoatie, R.J. 2012. Tata Ruang Air Tanah, Edisi Revisi. Yogyakarta: Penerbit Andi.

Peraturan Pemerintah No. 42 Tahun 2008 tentang Pengelolaan Sumber Daya Air

Yan, Shao-feng, dkk. (2014). Seasonal Variations in Groundwater Level and Salinity in Coastal Plain of Eastern China Influenced by
Climate. Hindawi Publishing Corporation Journal of Chemistry Volume 2015, Article ID 905190, 8 pages.

Slameto. 2010. Belajar dan Faktor-Faktor yang Mempengaruhinya. Jakarta: Rineka Cipta. 